\title{
INTEGRATED FARMING: THE WAY TO SUSTAINABLE AGRICULTURE IN LATVIA Kaspars Naglis-Liepa ${ }^{1}$ Dr.oec.; Dzidra Kreismane ${ }^{2}$ Dr.agr.; Laima Berzina ${ }^{3}$ Dr.sc.ing.;
} Olga Frolova ${ }^{4}$ Mg.sc.ing.; Elita Aplocina ${ }^{5}$ Mg.agr.

1, 2, 3, 4, 5 Latvia University of Life Sciences and Technologies

\begin{abstract}
Agricultural production is currently at a crossroads due to the need to balance the requirements of climate, biodiversity, air quality, and access to food health, farmers' incomes and economic conditions. These demands are often controversial, and the goals of policy makers are contradictory. Sustainability in agriculture needs to be put into practice. The concept of sustainable agriculture is based on agro-ecology and a system approach and aims to promote sustainable, resilient, cost-effective and stable farming systems. Based on the analysis of the scientific literature and the current situation, the paper authors have concluded that a logical path to sustainability is integrated agriculture. It is a whole farm management system that allows farmers to identify opportunities and threats and act accordingly, while also taking into account the interests of consumers in their business. The paper aims to outline the role of integrated agriculture in the development of sustainable agriculture based on the analysis of the relevant scientific literature and the current situation. Integrated management is the knowledge-based management of all available resources integrated farms are able to provide climate benefits, provide more diverse (especially pasture) land management, farm animals have a higher quality of life and survival.
\end{abstract}

Key words: sustainable agriculture, integrated agriculture, dairy, organic, agricultural land management. JEL code: Q54

\section{Introduction}

The concept of sustainable agriculture is based on agro-ecology and a system approach and aims to promote sustainable, resilient, cost-effective and stable farming systems. The International Organization for Biological and Integrated Control of Organic (IOBC) defines integrated farming according to the European standard UNI 11233-2009 as an agricultural system that produces high quality food, feed, fibre and renewable energy by using resources such as soil, water, air and nature and as well as regulating mechanisms to replace potentially polluting inputs and consequently ensure sustainable agricultural management (Bioagricert, 2020). Farming systems placing a focus on ecological objectives either reduce the amount of mineral fertilizer (e.g. integrated farming) and/or the stocking density or the amount of purchased feed (e.g. organic farming), thereby reducing the excess of nitrogen and other elements and their inputs into the soil. The integrated organic farming system ensures that organic residues and manure are processed; as a result, compared with conventional agriculture, 60 to $70 \%$ less $\mathrm{N}$ fertiliser is needed. In addition, the reduced nitrogen supply under the organic system requires careful and efficient agricultural management (Kramer et al., 2006). Researchers in their research studies conducted in various countries and under diverse conditions have found that many small farmers cope with and even prepare for climate change, as well as deal with the factors that affect yields by applying a range of agro-ecological techniques. Observations on the adaptation of agricultural activity to extreme climatic conditions over the last two decades have shown that resilience to climate disasters is strongly linked to the high level of biodiversity on the farms, which is a typical feature of traditional integrated farming systems. In view of this evidence, various experts have suggested that the promotion of traditional farming systems in combination with agroecological management could be the only real way to increase the productivity, sustainability and resilience of agricultural production under the projected climate scenarios. Biodiversity, soil management and moisture supply could be achieved through the development and management of agro-ecosystems, thereby enabling farmers to implement practices that both bring economic benefits and increase agricultural sustainability, including reducing global warming (Altieri, Nicholls, 2013). The mentioned considerations 
have been taken into account, and the EU developed the Farm to Fork Strategy, which is part of the European Green Deal that allows making the food system fair, healthy and environmentally-friendly (EC. Farm to Fork Strategy, 2020).

The paper aims to outline the role of integrated agriculture in the development of sustainable agriculture based on the analysis of the relevant scientific literature and the current situation.

\section{Results}

Integrated agricultural production focuses on managing ecological processes and their interactions on the farm to optimize the exploitation of the farm's internal resources, minimize the need for external resources and avoid or reduce the environmental impacts of agricultural practices, including GHG and ammonia emissions. Biodiversity is a basic element in the production of food and fibre under ecological farming systems. Many components of organic farming could be used to improve farming systems, including the conventional farming system. Sustainable and organic farming systems give many possibilities to reduce GHG emissions and global warming. For example, the organic farming system uses 25 to 50 \% less energy to produce food than conventional agriculture, which applies agrochemicals. C absorption by soil provides even greater potential for GHG reduction. Carbon absorption increases the organic matter content of the soil; therefore, it is important for all types of farming systems and farms. Productive and ecologically sustainable agriculture is crucial to reduce trade-offs between food security, climate change and ecosystem degradation (Willer, Kilcher, 2009). Many components of organic farming could also be integrated into other sustainable farming systems, e.g. integrated farming. A conception based on the system approach and equivalent to organic farming, combined with new sustainable technologies (e.g. no-till technology), can offer very much-needed solutions to climate change (Niggli, Fließbach, Hepperly, Scialabba, 2009).

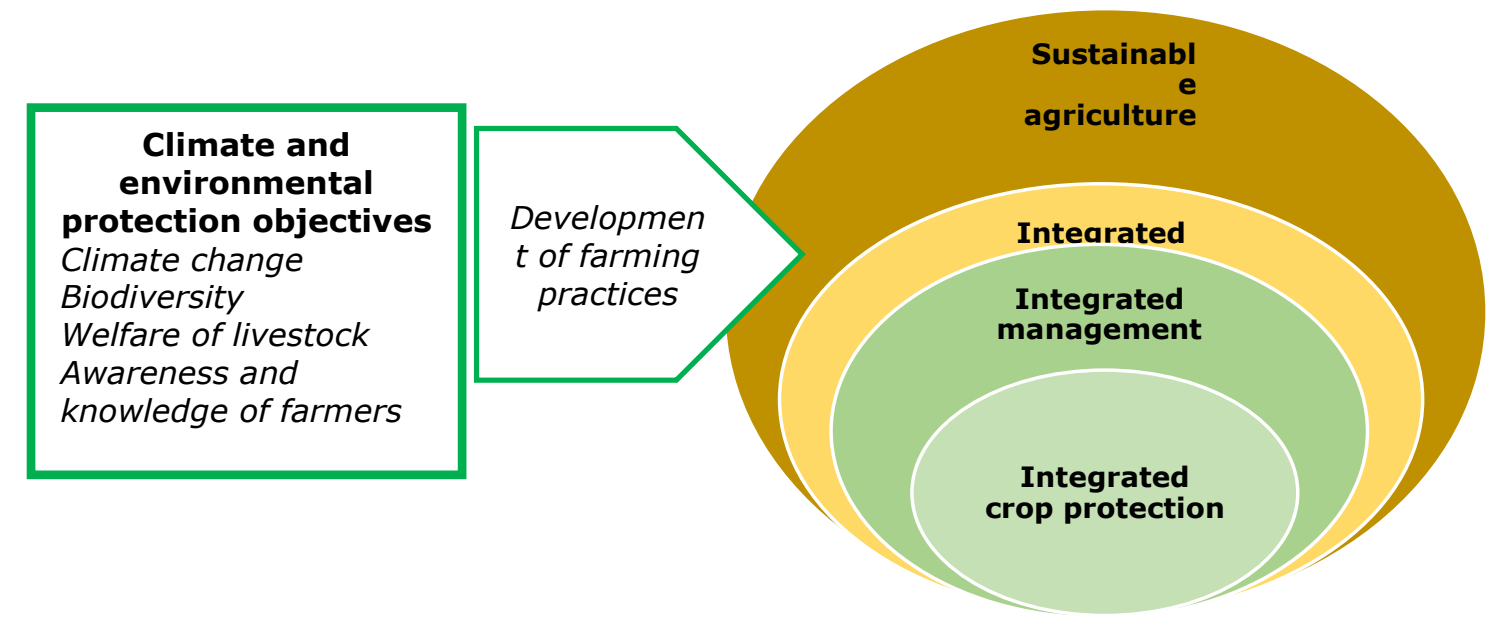

\section{Source: authors' construction}

\section{Fig. 1. Integrated farming in the context of sustainable agriculture}

Emissions of greenhouse gases and other air pollutants cannot be avoided if working outdoors, burning fossil fuels, keeping farm animals, storing and spreading manure, as well as carrying out other activities needed for the production of food. Integrated farming practices can help to preserve carbon stocks in soil by growing both annual and perennial crops, grasses, forests or plants in buffer zones (e.g. hedges, grasslands etc.). Minimum or reduced tillage, intercropping or incorporation of crop residues into the soil can even increase $\mathrm{C}$ absorption by the soil and also improve air quality. It is important to identify potential air pollutants and sources of emissions on the farm and develop emission reduction possibilities/strategies in order to reduce the potential emissions in particular. One of the most complete possibilities for emission reduction is a life cycle assessment, which can provide useful information. Applying the life cycle 
assessment methodology, research studies have shown that GHG emissions per area unit were 36 \% lower, per unit of production $18 \%$ lower and the dry matter yield was $22 \%$ lower in organic systems than in conventional systems. Most of the differences were due to $\mathrm{CO}_{2}$ and $\mathrm{N}_{2} \mathrm{O}$ emissions, both of which mainly relate to the application of fertilizers in conventional agriculture (Nemecek et al., 2006). Shifting to organic farming could reduce agricultural GHG emissions by approximately $20 \%$, as no industrially produced nitrogen fertilizers are applied. However, a complete shift to organic farming could reduce global yields. According to various research studies, the yield reduction could be 30 to $40 \%$ in areas practicing intensive farming under the best geo-climatic conditions. In less-favoured areas, crop losses are generally not observed. On subsistence farms and in areas having periodic water supply disruptions caused by droughts or floods, organic farming is more competitive than conventional farming and often yields are higher due to crop rotation and the inclusion of legumes in it. Consequently, organic farming has huge potential, both considering the recommendations of the IPCC Fourth Assessment Report and in terms of future food security (Badgley et al., 2007; Sanders, 2007).

Table 1

$\mathrm{N}_{2} \mathrm{O}$ emissions from $\mathbf{N}$ input into managed soils in the period in Latvia 2014-2018, kt

\begin{tabular}{|l|c|c|c|c|c|}
\hline \multicolumn{1}{|c|}{ Source of emissions } & $\mathbf{2 0 1 4}$ & $\mathbf{2 0 1 5}$ & $\mathbf{2 0 1 6}$ & $\mathbf{2 0 1 7}$ & $\mathbf{2 0 1 8}$ \\
\hline Inorganic nitrogen fertilizer & 1.15 & 1.19 & 1.23 & 1.22 & 1.17 \\
\hline Manure & 0.26 & 0.26 & 0.25 & 0.24 & 0.21 \\
\hline Sludge & 0.006 & 0.004 & 0.003 & 0.003 & 0.004 \\
\hline Urine and manure of grazing animals & 0.18 & 0.19 & 0.20 & 0.20 & 0.20 \\
\hline Crop residues & 0.41 & 0.51 & 0.48 & 0.49 & 0.39 \\
\hline Managed organic soil in pastures and crop areas & 2.66 & 2.64 & 2.62 & 2.63 & 2.63 \\
\hline
\end{tabular}

Source: authors' calculations based on the National Inventory Report, 2020.

An increase in the consumption of inorganic fertilizers is due to several factors, yet the most significant one is an increase in the number of large farms and the area managed by them. Farms with a standard output of over EUR 500 thou. increased by $39 \%$ between 2013 and 2016, while the total number of farms decreased by $15 \%$. It should be noted that large farms are usually conventional and intensive farms. Farming systems placing a focus on ecological objectives either reduce the amount of mineral fertilizer (e.g. integrated farming) and/or the stocking density or the amount of purchased feed (e.g. organic farming), thereby reducing the excess of nitrogen and other elements and their inputs into the soil. The integrated organic farming system ensures that organic residues and manure are processed; as a result, compared with conventional agriculture, 60 to $70 \%$ less $\mathbf{N}$ fertiliser is needed. In addition, the reduced nitrogen supply under the organic system requires careful and efficient agricultural management (Kramer et al., 2006).

On the one hand, such farms are more cost-effective, on the other hand, they use less pasture, which is an essential precondition for sustainable farming and the contribution of agriculture to the preservation of biodiversity. 


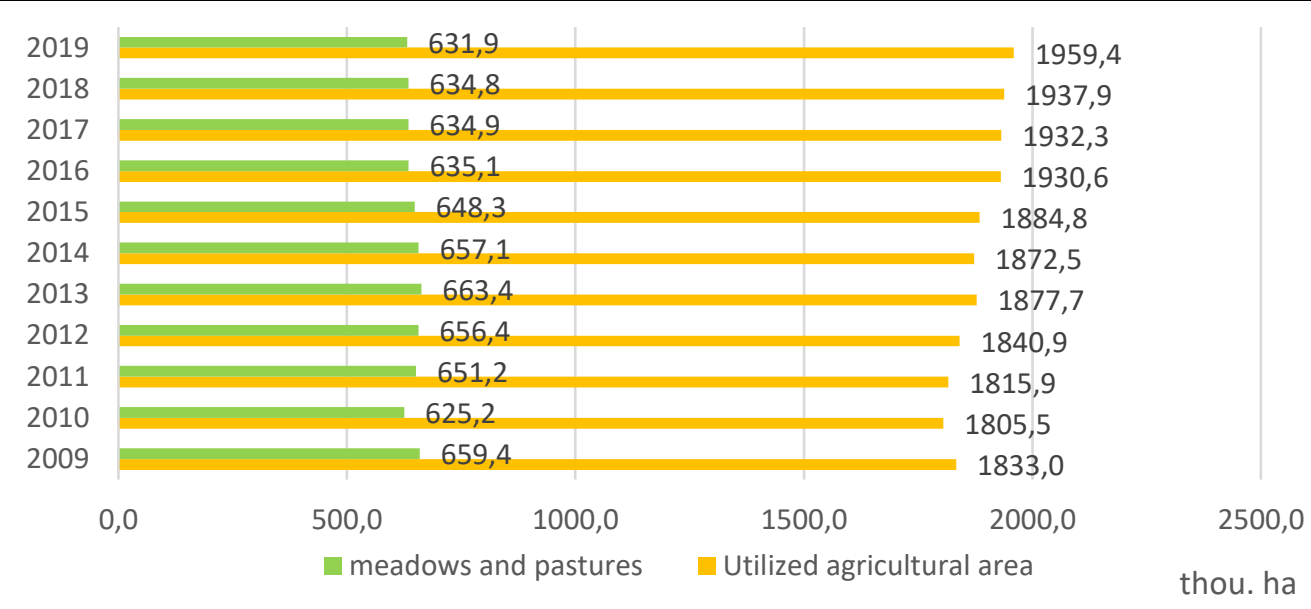

Source: authors' construction based on the CSB

Fig. 2. Uses of agricultural land in Latvia (thou. hectares)

Owing to the environmental policy guidelines, it is not possible to significantly reduce the amount of meadows and pastures, which means that practically the only way to manage them economically is to produce livestock products. Besides, according to the available information, there are 158.3 thou. ha of organic soils in Latvia, which cause ten times more emissions per area unit than mineral soils do, and it is now difficult to use these lands for economic activity (National Inventory Report. Latvia, 2020). The recast Renewable Energy Directive (2018/2001) provides for the non-use of such lands for renewable energy purposes, which means that crops grown on such soils cannot be used for energy production. At the same time, there is a possibility that the area of meadows will increase even more, as half of the organic soils are arable land, the use of which would be difficult if taking into account the ten times higher GHG emission potential. About half of the grasslands in Latvia are currently used, while the rest are simply moved. In summary, animal production practices are essential for the management of agricultural land. Integrated crop and animal production as well as cooperation between specialized farms is the basis for the proper management and use of manure, as well as for the diversification of production in various agricultural industries, with a particular focus on the diversity of food crops and fodder crops and the cultivation of leguminous grasslands. The concept of mixed farms or close cooperation between crop and livestock farms, especially organic ones, can significantly reduce nutrient leaching and water pollution, carbon dioxide $\left(\mathrm{CO}_{2}\right)$, nitrous oxide $\left(\mathrm{N}_{2} \mathrm{O}\right)$ and methane $\left(\mathrm{CH}_{4}\right)$ emissions. In addition, under organic farming systems, the use of various forms of compost, especially composted manure, can increase the microbiological activity of the soil and contribute to the stable formation of soil organic matter (Fließbach, Mäder, 2000) 


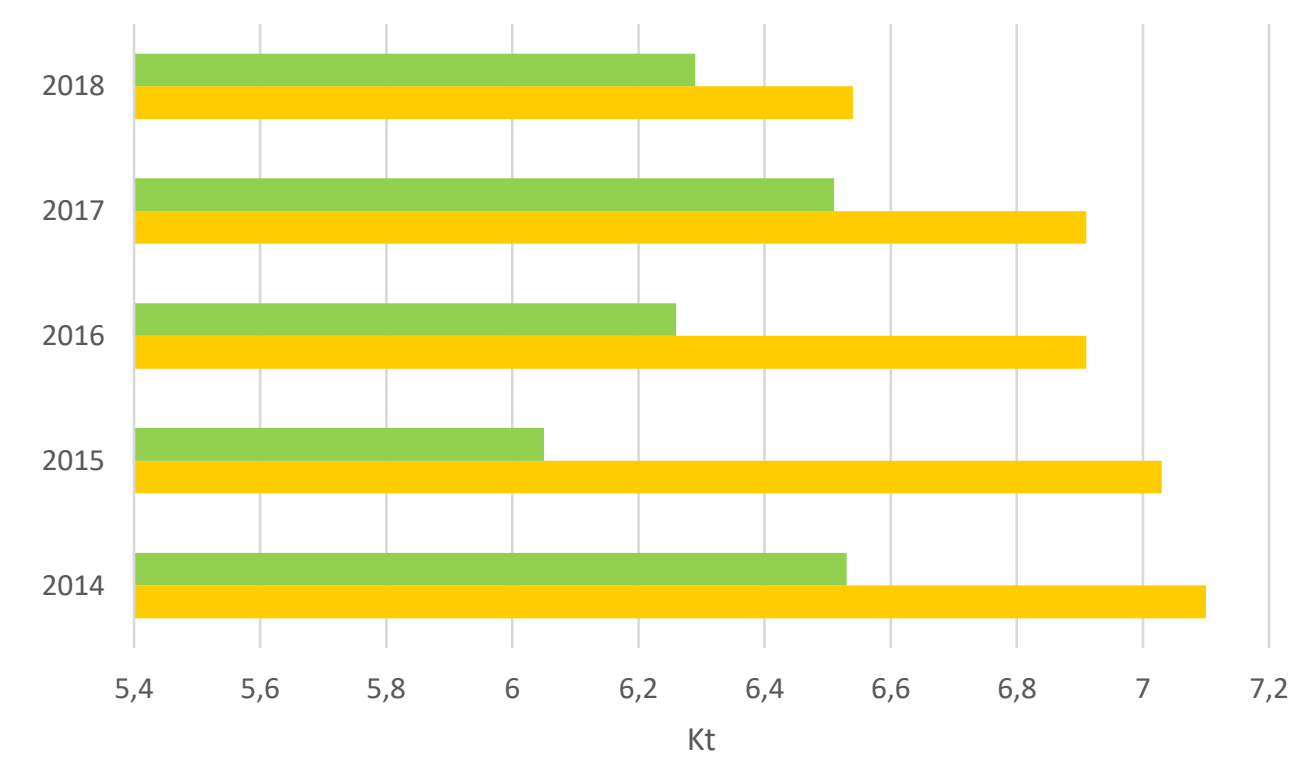

Crop production, inorganic fertiliser application manure management

Source: authors' construction based on Latvia's Informative Inventory..., 2020.

\section{Fig. 3. Ammonia emissions from manure management and crop production} and fertilizer application in Latvia in the period 2014-2018, kt

The living space of livestock is just one of the indicators of animal welfare. Science refers to three preconditions for animal welfare - the animal function well (e.g. good health, productivity etc.), the animal feeling well (e.g. absence of pain etc.), the animal able to live according to its nature (e.g. perform natural behaviours that are thought to be important to it, such as grazing) (Von Keyserling, et al., 2009). The possibility of livestock to graze significantly improves their quality of life and at the same time reduces GHG emissions. Large intensive livestock farms usually keep their livestock indoors and do not graze animals. The lifespan of livestock is a closely related aspect. One of the most common reasons for excluding cows from herds is unsuccessful insemination - $23.9 \%$ of all the discarded cows. The second, no less important reason relates to udder health (mastitis, quarter dysfunction, udder injuries), which together make up $26.1 \%$ of the discarded cows. Only a small proportion of cows are discarded due to age and infertility. This means that most of the dairy farms practise forced rather than selective cow discarding. Forced discarding makes up $88.6 \%$, while selective $11.4 \%$ of the total cases. The economic benefits could also be increased by reducing forced livestock discarding. It is more efficient to use selective discarding. The average number of cows discarded per year is in the range of 16-26\%. It is considered that the herd is managed effectively if the cows produce at least $32000 \mathrm{~kg}$ of milk during their lifespan and $15 \mathrm{~kg}$ of milk a day, the cows have at least 3.5 lactations, and first calving is at the age of 24 months. The age of first calving is one of the factors affecting the lifespan of the cow and the cow's productivity during the subsequent lactations (Bimsteine, 2017). The reasons for the higher discarding rate for cows during lactation were lower milk yields, the somatic cell count above $200000 \mathrm{~mL}^{-1}$ and the fat/protein ratio above 1.5 during early lactation. The highest probability of discarding cows was for those from larger herds and having higher milk yields (Rilanto, Reimu, Orro et al., 2020). Livestock breeds should also be taken into account when assessing the milk productivity and lifespan of dairy cows. Several research studies have shown that cows in red breed cows have a longer lifespan than black-spotted cows, while black-spotted cows have higher productivity not only during lactation but also throughout the lifespan (Dillon et al., 2003). On the farm Vecauce, Latvian 
brown cows had a significantly longer lifespan, which were discarded on average 1.3 years later than Holstein Black and White cows (Cielava, Jonkus, Paura, 2015).

Table 2

Characteristics of dairy cows and farms in Latvia 2019

\begin{tabular}{|c|c|c|c|c|c|c|c|c|}
\hline \multirow{2}{*}{$\begin{array}{c}\text { Kind of dairy } \\
\text { cows }\end{array}$} & \multirow{2}{*}{$\begin{array}{l}\text { Number } \\
\text { of cows }\end{array}$} & \multirow{2}{*}{$\begin{array}{l}\text { As } \\
\% \text { of } \\
\text { total } \\
\text { cows }\end{array}$} & \multirow{2}{*}{$\begin{array}{l}\text { Number } \\
\text { of farms }\end{array}$} & \multirow{2}{*}{$\begin{array}{c}\text { As } \% \text { of } \\
\text { total } \\
\text { farms }\end{array}$} & \multicolumn{2}{|c|}{ Milk yield, kg } & \multicolumn{2}{|c|}{ Lactations } \\
\hline & & & & & avg. & wavg. & avg. & wavg. \\
\hline Organic & 17751 & 13.6 & 880 & 21.4 & 5861.00 & 5742.00 & 4.28 & 4.0 \\
\hline $\begin{array}{l}\text { Intensive } \\
(>\mathbf{3 0 0})\end{array}$ & 36394 & 27.9 & 64 & 1.6 & 9799.70 & 9839.70 & 3.04 & 3.0 \\
\hline $\begin{array}{l}\text { Conventional } \\
\text { home farm } \\
(<5)\end{array}$ & 1883 & 1.4 & 654 & 15.9 & 6185.51 & 6162.30 & 4.48 & 4.3 \\
\hline $\begin{array}{l}\text { Conventional (5 } \\
-300 \text { ) }\end{array}$ & 74318 & 57.0 & 2523 & 61.2 & 6634.96 & 7394.69 & 3.94 & 3.5 \\
\hline
\end{tabular}

Source: authors' calculations based on the ADC 33

The milk yield is $41 \%$ higher on intensive livestock farms than on organic farms and $37 \%$ higher than on small conventional farms, which mostly use pastures. At the same time, it should be noted that neither type of cow keeping in itself provides a higher milk yield. It is an complex of activities, ranging from the selection of breeds to diets and rations. On the other hand, organic and home farms have a higher number of lactations, which mostly means a longer lifespan for the cows. On organic and home farms, cows live longer, in some cases the entire lifetime, which is not possible in intensive farming, leading to a rapid deterioration in cow health and their discarding.

Agricultural production is a complex kind of business because the amount of knowledge needed and the flow of relevant information is very significant. Knowledge management plays a crucial role in sustainable agriculture. Large farms usually have a large amount of knowledge and information that they manage through outsourced services. In contrast, small farms usually experience a significant lack of knowledge without proper contact with agricultural advisers, thereby leading to unsustainable production, including financial losses (Labarthe, Laurent, 2013). This is particularly important with regard to environmental awareness. It includes five dimensions: a) environmental knowledge; b)environmental values; c) environmental concern; d) connectedness to Nature; e) environmental attitudes; and f) environmental behaviour. It is easy to understand that farmers involved in sustainable farming practices such as integrated and organic farming are more environmentally conscious (Despetovic et al., 2021) A multidisciplinary perspective of farmers' competencies, emphasizing environmental awareness, confirms that farmers of integrated agricultural practices are forced to devote much more time to learning, and financial motivation is less necessary.

\section{Conclusions, proposals, recommendations}

1) Climate and environmental protection requirements tend to increase, which requires a review of farming practices, especially in animal production.

2) Integrated and organic farms produce less GHG emissions, absorb more C (mixed type farms) and have higher resilience to various shocks.

3) Integrated and organic farms are able to manage organic soils by means of pastures, which is not typical of conventional intensive farms. 
4) Integrated and organic farms ensure a higher quality of life for farm animals, which involves keeping them in natural conditions (pastures) and feeding a better diet, which results in more lactations and a longer lifespan. It should be noted that this also means lower GHG emissions, as cow discarding is reduced and fewer offspring are required.

5) Integrated and organic farms are more knowledge intensive, which increases their environmental awareness compared with conventional farms.

\section{Acknowledgement}

The paper is supported by the project "Adapting Marginal Abatement Cost Curves (MACC) for Agricultural Greenhouse Gas and Ammonia Emissions as well as $\mathrm{CO}_{2}$ Sequestration (in Arable Land and Grasslands) in Latvia for Use in Agricultural, Environmental and Climate Policy-Making by the Ministry of Agriculture of the Republic of Latvia (No. 10.9.1-11/18/929-e)

\section{Bibliography}

1. Altieri, M.A., Nicholls, C.I. (2013). The Adaptation and Mitigation Potential of Traditional Agriculture in a Changing Climate. Clim Chang. DOI:10.1007/s10584-013-0909-y

2. Badgley, C., Moghtader, J., Quintero, E., Zakem, E., Chappell, M.J., Aviles-Vazquez, K., Samulon, A., Perfecto, I. (2007). Organic Agriculture and the Global Food Supply. Renewable Agriculture and Food Systems 22, pp. 86-108.

3. Bimsteine, Z. (2017). Slaucamo govju ilgmuziba un ganampulka apsaimniekosana (Dairy Cow Lifespan and Herd Management). Retrieved: http://new.Ilkc.Iv/lv/nozares/lopkopiba/slaucamo-govju-ilgmuziba-unganampulka-apsaimniekosana. Access: 10.11.2020.

4. Bioagricert, UNI 11233: 2009 Integrated Production Systems in Agricultural Food Chains - General Principles for Design and Implementation in Vegetal Food Chains. Retrieved: https://www.bioagricert.org/en/certification/product-quality/integrated-production.html. Access: 25.02.2021.

5. Cielava, L., Jonkus, D., Paura, L. (2015). Slaucamo govju piena produktivitates un muza garuma izmainas LLU MPS "Vecauce" (Changes in the Milk Productivity and Lifespan of Dairy Cows on the LLU Research and Training Farm Vecauce). No: Lauksaimniecibas zinatne reorganizacijas laika. Razas svetki "Vecauce - 2015" (In: Agricultural Science during Reorganisation. Harvest Festival Vecauce-2015), pp.17-20.

6. Despotovic, J., Rodic, V., Caracciolo, F. (2021). Farmers Environmental Awareness: Construct Development, Measurement, and Use. Journal of Cleaner Production. Vol. 295. 126378

7. Dillon, P., Snijders, S., Buckley, F. (2003). A Comparison of Different Dairy Cow Breeds on Seasonal Grassbased System of Milk Production 2. Reproduction and Survival. Livestock Production Science, pp. 35-42.

8. European Commission (2020). Farm to Fork Strategy. For a Fair, Healthy and Environmentally-friendly Food System.

9. Fließbach, A., Mäder, P. (2000). Microbial Biomass and Size-density Factions Differ between Soils of Organic and Conventional Agricultural Systems. Soil Biology \& Biochemistry. No. 32, pp. 757-768.

10. Kramer, S. B., Reganold, J. P., Glover, J. D., Bohannan, B. J. M., Mooney, H. A. (2006). Reduced Nitrate Leaching and Enhanced Denitrifier Activity and Efficiency in Organically Fertilized Soils. In: Proceedings of the National Academy of Sciences of the USA. Vol. 103, pp. 4522-4527.

11. Labarthe, P., Laurent, C. (2013). Privatization of Agricultural Extension Services in the EU: Toward a Lack of Adequate Knowledge for Small-scale Farmers. Food Policy. Vol. 38, pp. 240-252.

12. National Inventory Report. Latvia (2020) Retrieved: https://unfccc.int/documents/227704: Access: 21.02.2021.

13. Nemecek, T., Dubois D., Huguenin-Elie, O., Gaillard, G. (2006). Life Cycle Assessment of Swiss Organic Farming Systems. Aspects of Applied Biology, No. 79, pp. 15-18.

14. Niggli, U., Fließbach, A., Hepperly, P., Scialabba, N. (2009). Low Greenhouse Gas Agriculture: Mitigation and Adaptation Potential of Sustainable Farming Systems. FAO. April 2009. Rev. 2.

15. Rilanto, T. Reimu, K., Orro T., Emanuelson, U., Viltrop, A., Mõtus, K. (2020). Dairy Cow Culling - Reasons and Risk Factors. BMC Veterinary Research. 16:173. pp. 2-16. Retrieved: https://doi.org/10.1186/s12917-02002384-6. Access: 21.02.2021.

16. Sanders, J. (2007). Economic Impact of Agricultural Liberalisation Policies on Organic Farming in Switzerland. PhD thesis. Aberystwyth University.

17. Von Keyserling, M.A.G., Rushen, J., de Passille, A.M., Weary, D.M. (2009). Invited Review: The Welfare of Dairy Cattle - Key Concepts and the Role of Science. Journal of Dairy Science. Vol. 92. issue 9, pp. 4101-4111.

18. Willler, H., Kilcher, L. (Eds.) (2009). The World of Organic Agriculture. Statistics and Emerging Trends 2009. IFOAM. DE-Bonn and FiBL. CH-Frick. 